\title{
Market Basket Analysis Pada Mini Market Ayu Dengan Algoritma Apriori
}

\author{
Erlin Elisa \\ Dosen Sistem Informasi Universitas Putera Batam \\ Jl. R.Suprapto Muka Kuning-Batam \\ elin110110@gmail.com \\ Submitted: 10-10-2017, Reviewed: 26-10-2017, Accepted 03-11-2017 \\ http://dx.doi.org/10.22202/jei.2017.v4i1.2641
}

\begin{abstract}
ABSTRAK
Data mining merupakan teknik untuk menggali informasi baru dari gudang data, informasi dipandang sangat penting dan berharga karena dengan menguasai informasi maka dengan mudah untuk mencapai sebuah tujuan, hal ini membuat setiap orang berlomba untuk memperoleh informasi, demikian juga pada usaha perdagangan seperti minimarket Ayu di Kota Batam. Minimarket ini berlokasi dekat dengan rumah penduduk, hal ini tentunya mempengaruhi tingkat penjualan, dengan adanya kegiatan penjualan setiap hari, data transaksi penjualan akan terus bertambah, menyebabkan penyimpanan data semakin besar. Data transaksi penjualan hanya dijadikan arsip tanpa dimanfaatkan dengan baik. Pada dasarnya kumpulan data memiliki informasi yang sangat bermanfaat. Analisis keranjang pasar dengan Algoritma Apriori merupakan salah satu metoda data mining yang bertujuan untuk mencari pola assosiasi berdasarkan pola belanja yang dilakukan konsumen, sehingga bisa diketahui item-item barang apa saja yang dibeli secara bersamaan, Hasil dari penelitian ini menemukan Nilai support dan confidence tertinggi adalah Minyak dan Susu dengan nilai support $41,85 \%$ dan confidence $85,71 \%$.
\end{abstract}

Kata kunci: Data Mining, Analisa Keranjang Pasar, Metode Asosiasi, Algoritma Apriori.

\begin{abstract}
Data mining is a technique to extract new information from the data warehouse, informati on is considered very important and valuable because by mastering the information so eas ily to achieve a goal, this makes everyone competing to obtain information, as well as on trading businesses such as minimarket Ayu in Kota Batam. Minimarket is located close $t$ $o$ the home of the population, this certainly affects the level of sales, with the daily sales activities, sales transaction data will continue to grow, causing data storage is greater. Sa les transaction data is only used as an archive without being put to good use. Basically $t$ he data set has very useful information. The analysis of market basket with Apriori Algori thm is one method of data mining which aims to find the pattern of association based on consumer spending pattern, so that it can be known what items are purchased simultaneo usly. The result of this research found that the highest support and confidence value is Oil and Milk with a support value of $41.85 \%$ and confidence of $85.71 \%$.
\end{abstract}

Keywords : Data Mining, Market Basket Analysis, Association Rules, Apriori Algorithms 


\section{PENDAHULUAN}

Pertumbuhan perekonomian masyarakat diikuti dengan pertumbuhan bisnis ritel yang semakin pesat. Indonesia dengan jumlah penduduk ke-empat terbanyak di dunia setelah Cina dan India memiliki potensi yang sangat besar bagi pasar ritel. Salah satu jenis pasar modern yang saat ini sedang berkembang pesat menawarkan kemudian karena lokasi toko atau gerai yang dekat dengan konsumen serta mengutamakan kepraktisan dan kecepatan atau waktu yang tidak lama dalam berbelanja. (Subarsono, 2014). Salah satu ritel yang kita kenal adalah minimarket.

Minimarket merupakan sebuah usaha yang memiliki prospek bisnis yang menguntungkan pada saat sekarang ini, sebagaimana yang kita ketahui minimarket adalah sebuah tempat yang kecil tetapi menjual barang-barang bervariatif dan lengkap seperti yang ada didalam pasar, sebuah minimarket sebenarnya adalah semacam toko kelontong atau yang menjual segala macam barang dan makanan, perbedaannya disini minimarket telah menggunakan konsep sistem swalayan dimana pembeli mengambil sendiri barang yang ia butuhkan dari rak-rak minimarket dan membayarnya di meja mesin kasir.

Potensi bisnis minimarket Indonesia 2017 akan lebih baik dibandingkan dengan tahun lalu. Para pelaku retail mematok pertumbuhan bisnis ritel Indonesia mencapai $12 \%$, angka ini menurut data Aprindo (Asosiasi Pengusaha Ritel Indonesia) pertumbuhan retail 2016 optimis berada diangka 10\% lebih baik dari 2015 yang hanya mencapai $8 \%$. Salah satu jenis usaha ritel yang masih sangat prospektif adalah adalah minimarket. Menurut penelitian (Subarsono, 2014). pada jurnal penelitiannya yang berjudul perbedaan pelayanan pada ritel tradisional dengan ritel modern menyebutkan Industri ritel tumbuh pesat dengan menjamurnya pasar modern. Yang dimaksud dengan pasar modern adalah minimarket atau swalayan yang mana pelayanan dilakukan sendiri oleh konsumen karena toko tidak menyediakan pramuniaga yang khusus melayanan konsumen. Salah satu jenis pasar modern yang saat ini sedang berkembang pesat menawarkan kepraktisan dan kecepatan atau waktu yang tidak lama dalam berbelanja dengan didukung luas dari toko atau gerai tidak terlalu besar, sekitar 90150 meter persegi dan menjual 3.000-4.000 jenis barang.

Pada saat sekarang ini jumlah minimarket terus berkembang membuat para pengelola minimarket juga dituntut untuk menerapkan strategi pemasaran yang lebih baik. Untuk itu maka para pengelola harus mencermati pola-pola pembelian yang dilakukan oleh konsumen seperti usaha minimarket di kota batam. Kota batam merupakan kota dengan pertumbuhan ekonomi yang baik salah satunya dapat dilihat dari banyaknya usaha ritel seperti minimarket, usaha minimarket ini sangat diminati oleh pedagang baik yang berasal dari luar kota batam maupun pribumi karena hasil keuntungan yang diperoleh dari usaha ini sangat menjanjikan. Minimarket ayu sebagai salah satu minimarket yang lokasinya strategis dekat komplek perumahan dan sekolah tentunya kegiatan penjualan pada setiap harinya meningkat. Dengan meningkatnya jumlah penjualan maka, ditemukan banyak kekurangan yang terjadi, diantaranya permasalahan peletakkan barangbarang yang tidak sesuai dengan perilaku kebiasaan konsumen dalam membeli barang secara bersamaan dalam satu waktu. Hal ini tentu akan mempengaruhi tingkat penjualan barang. Data transaksi penjualan akan terus bertambah setiap harinya dan menyebabkan penyimpanan data yang sangat besar. Kebanyakan data transaksi penjualan hanya dijadikan arsip saja tanpa dimanfaatkan dengan baik. Padahal kumpulan data tersebut memiliki informasi yang sangat bermanfaat.

Berdasarkan permasalahan di atas, maka pada minimarket ayu diperlukan adanya teknik data mining untuk mengelompokkan data barang berdasarkan kecenderungannya yang muncul bersamaan dalam suatu transaksi, Market Basket Analysis atau analisa keranjang pasar adalah suatu metode yang bekerja mencari dan menemukan polapola yang berasosiasi diantara produk-produk yang dipasarkan, misalnya menemukan bahwa produk A biasanya dibeli bersamaan dengan produk B dalam waktu tertentu dan jumlah tertentu. Teknik ini merupakan salah satu cara untuk melakukan data mining yang berguna untuk menemukan knowledge dari 
data-data yang ada (Santony, 2012). Knowledge tersebut dapat digunakan oleh perusahaan untuk meningkatkan keuntungan atau menentukan strategi pemasaran.

\section{TINJAUAN PUSTAKA}

\subsection{Penelitian Terdahulu}

Berdasarkan pengamatan penelitan terdahulu tentang Penerapan Metode Association Rule Menggunakan Algoritma Apriori Pada Simulasi Prediksi Hujan Wilayah Kota Bandung". Dataset yang digunakan adalah data klimatologi yang diambil dari BMKG stasiun geofisika kelas 1 Bandung. Hasil akhir dari Penelitian ini berupa aturan-aturan asosiasi (association rules) dimana aturan-aturan ini dapat dijadikan sebagai acuan dalam memprediksi cuaca hujan atau tidak hujan untuk satu hari kedepan (Fauzy \& Asror, 2016).

Sedangkan pengamatan pada penelitian tentang Pemanfaatan Algoritma Apriori untuk Perancangan Ulang Tata Letak Barang di Toko Busana", Penelitian ini menggunakan algoritma Apriori untuk menganalisis pola belanja konsumen (market basket analysis) di toko busana muslimah karena pertimbangan masih sedikitnya penelitian dalam konteks serupa. Hasil penelitian berupa sistem berbasis web yang menghasilkan aturan asosiasi sehingga penataan ulang bisa dilakukan secara dinamis Pengujian dengan dataset baru dan perbandingan dengan Weka membuktikan bahwa sistem berhasil menerapkan algoritma Apriori. Keberhasilan dinilai berdasarkan kesamaan aturan asosiasi pada Weka dengan aturan asosiasi pada sistem (Wulandari, 2014). Algoritama apriori digunakan karena algoritma ini merupakan teknik asosiasi yang sederhana untuk menentukan pola pembelian konsumen dan memperkirakan di masa yang akan datang untuk menata barang dalam keadaan yang dinamis.

\subsection{Data Mining}

Secara umum tahapan - tahapan proses Knowledge Discovery in Databases terdiri dari (Han dan Kamber,2006):

\section{Data Cleaning}

Proses menghilangkan noise dari data yang tidak konsisten.

\section{Data Integration}

Penggabungan Data dari berbagai database ke dalam satu database baru.

\section{Data Selection}

Proses pemilihan data yang relevan yang didapat dari database.

4. Data Tranformation

Data diubah ke dalam format yang sesuai untuk diproses dalam Data Mining .

\section{Data Mining}

Suatu metode yang diterapkan untuk menemukan pengetahuan berharga yang tersembunyi dari data.

\section{Parttern Evaluation}

Mengidentifikasi pola-pola menarik untuk dipresentasikan ke dalam knowlwdge based.

\section{Knowledge Presentation}

Visualisasi dan penyajian pengetahuan mengenai teknik yang digunakan untuk memperoleh pengetahuan yang diperoleh oleh user.

Knowledge discovery in database (KDD) pada intinya adalah proses menemukan pengetahuan yang bermanfaat dari kumpulan data. A. Berstein dkk. Juga mendefinisikan knowledge discovery in database (KDD) sebagai hasil proses penjelajahan yang melibatkan penerapan berbagai Prosedur algoritma untuk memanipulasi data, membangun model dari data, dan memanipulasi model (Gamarra et al, 2016). Menurut Turban dalam bukunya yang berjudul "Decision Support Systems and Intelligent Systems", data mining adalah suatu istilah yang digunakan untuk menguraikan penemuan pengetahuan di dalam basis data. Data mining adalah proses yang menggunakan teknik statistik, matematika, kecerdasan buatan, dan machine learning untuk mengekstraksi dan mengidentifikasi informasi yang bermanfaat dan pengetahuan yang terkait dari berbagai basis data besar (Gunadi \& Sensuse, 2012).

\subsection{Teknik Asosiasi}

Menurut Larose dalam bukunya yang berjudu 1 "Discovering Knowledge in Data: An Introd uction to Data Mining", data mining dibagi 
menjadi beberapa kelompok berdasarkan tug as atau pekerjaan yang dapat dilakukan $(\mathrm{Gu}$ nadi \& Sensuse, 2012). salah satunya yaitu as sosiasi, tugas asosiasi dalam data mining adal ah menemukan attribu yang muncul dalam satu waktu. Dalam dunia bisnis lebih umum disebut analisis keranjang belanja. Contoh as osiasi dalam bisnis dan penelitian adalah:

1. Meneliti jumlah pelanggan dari perusahaan telekomunikasi seluler yang diharapkan untuk memberikan respon positif terhadap penawaran upgrade layanan yang diberikan.

2. Menentukan barang dalam supermarket yang dibeli secara bersamaan dan yang tidak pernah dibeli secara bersamaan.

\subsection{Market Basket Analysis}

Market Basket Analysis membantu pengecer dalam merencanakan item, untuk dijual dengan harga yang lebih murah . Han, Cheng dan Xin (2007) mengatakan bahwa Market Basket Analysis dapat meningkatkan penjualan dengan melakukan pemasaran selektif serta mengatur ruang rak .(Putro et al, 2016).

Ide yang mendasari Market Basket Analysis adalah asosiasi keputusan pembelian pada kosumen, misalnya, saat berbelanja di supermarket, pelanggan jarang membeli Satu produk, mereka jauh lebih mungkin untuk membeli seluruh keranjang produk, biasanya dari kategori produk yang berbeda. Menggunakan Informasi tentang market basket memungkinkan orang untuk menganalis data pada prosesenya tidak hanya mengekstrak kategori produk dan produk yang cenderung Dibeli bersama, tapi juga untuk menentukan produk mana atau kategori produk tertentu. Pengetahuan ini memungkinkan para manajer untuk mengembangkan intervensi yang bertujuan mempengaruhi perilaku pembelian, termasuk merangsang permintaan secara keseluruhan, mempromosikan kategori produk tertentu, atau penawaran Promosi untuk penjualan produk yang cenderung meningkatkan (Solnet et al, 2016).

\subsection{Algoritma Apriori}

Algoritma apriori adalah adalah algoritma yang paling terkenal untuk menemukan pola frekuensi tinggi. algoritma apriori dibagi menjadi beberapa tahap yang disebut narasi atau pass Pembentukan kandidat itemset, kandidat $k$-itemset dibentuk dari kombinasi (k-1)-itemset yang didapat dari iterasi sebelumnya. Satu cara dari algoritma apriori adalah adanya pemangkasan kandidat $k$ itemset yang subset-nya yang berisi (k-1) item tidak termasuk dalam pola frekuensi tinggi dengan panjang k-1 (Buulolo, 2017).

Algoritma apriori adalah salah satu algoritma yang melakukan pencarian frequent itemset dengan menggunakan teknik association rule. Untuk mencari association rule dari suatu kumpulan data, tahap pertama yang harus dilakukan adalah mencari frequent itemset terlebih dahulu. Frequent itemset adalah sekumpulan item yang sering muncul secara bersamaan. Penting tidaknya suatu asosiasi dapat diketahui dengan dua tolak ukur, yaitu support dan confidence. Support adalah nilai penunjang atau persentase kombinasi sebuah item dalam database, sedangkan confidence adalah nilai kepastian yaitu kuatnya hubungan antar item dalam aturan asosiasi. Proses utama yang dilakukan dalam algoritma apriori untuk mendapat frequent itemset. (Santoso et al., 2016).

Adapun metodologi dasar analisis asosiasi adalah sebagai berikut :

a) Analisis Pola Frekuensi Tinggi

Tahapan ini mencari kombinasi item yang memenuhi syarat minimum dari nilai support dalam database. Nilai support sebuah item diperoleh dengan rumus berikut.

$$
\text { Support }(A)=\frac{\text { Jumlah Transaksi Mengandung A }}{\text { Total Transaksi }}
$$

Sedangkan nilai support dari 2 item diperoleh 
dari rumus berikut.

Support $(A, B)=\frac{\sum \text { Transaksi Mengandung Adan } B}{\text { Total Transaksi }}$

b) Pembentukan Aturan Asosiasi

Pembentukan Aturan Asosiasi Setelah semua pola frekuensi tinggi ditemukan, barulah dicari aturan asosiasi yang memenuhi syarat minimum untuk confidence dengan menghitung confidence aturan asosiasif " jika A maka $\mathrm{B}$ “. Nilai confidence dari aturan " jika A maka $\mathrm{B}$ " diperoleh dari rumus berikut.

\section{Confidence $(A \mid B)=$ \\ $\sum$ Transaksi Mengandung Adan $B$ \\ ¿Transaksi Mengandung A}

\section{Metodologi Penelitian}

\subsection{Desain Penelitian}

Desain penelitian ini merupakan langkahlangkah yang akan dilakukan dalam penyelesaian masalah. Adapun desain penelitian ini dapat dilihat pada Gambar 1 .

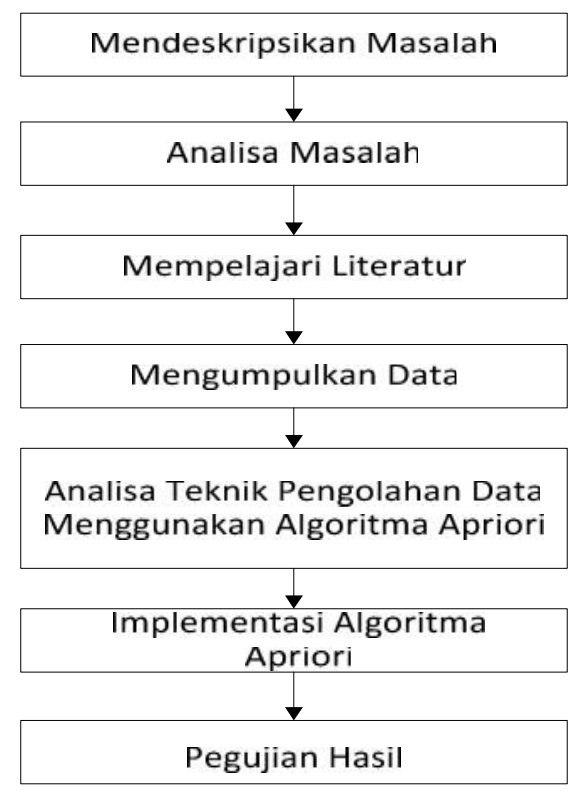

Gambar 1. Desain penelitian

Berdasarkan desain penelitian pada Gambar 1, maka masing-masing langkahnya dapat diuraikan seperti berikut ini :

1. Mendeskripsikan Masalah

(2) Mendeskripsikan masalah yang akan teliti perlu ditentukan terlebih dahulu. Mendeskripsikan masalah dalam penelitian dengan menentukan dan mendefinisikan batasan masalah yang akan diteliti, sehingga membantu dalam mendapatkan suatu solusi yang terbaik dari masalah tersebut. Jadi, langkah pertama ini adalah langkah awal yang terpenting dalam penelitian ini.

2. Analisa Masalah

Langkah analisis masalah merupakan langkah untuk dapat memahami masalah yang telah ditentukan ruang lingkup atau batasannya. Dengan menganalisis masalah yang telah ditentukan tersebut, maka diharapkan masalah dapat dipahami dengan baik.

3. Mempelajari Literatur

Untuk mencapai tujuan, maka dipelajari beberapa literatur-literatur yang diperkirakan dapat digunakan. Kemudian literatur-literatur yang dipelajari tersebut diseleksi untuk dapat ditentukan literatur-literatur mana yang akan digunakan dalam penelitian.

4. Mengumpulkan Data

Dalam pengumpulan data dilakukan observasi yaitu pengamatan secara langsung di minimarket ayu sehingga permasalahan yang ada dapat diketahui secara jelas. Kemudian dilakukan interview yang bertujuan untuk mendapatkan informasi atau data yang dibutuhkan. Selain itu juga dilakukan studi kepustakaan yaitu dengan membaca buku-buku yang menunjang dalam melakukan analisis terhadap data dan informasi yang didapat. Analisa teknik pengolahan data menggunakan algoritma apriori. Data yang diperoleh dari tempat penelitian selanjutnya dilakukan analisa dan pengolahan menggunakan algoritma apriori.

5. Perancangan Algoritma Apriori 
Pada tahap ini akan dilakukan proses perancangan dari model sistem dengan algoritma apriori sehingga diperoleh nilai support dan Confidence dan menghasilkan suatu rule pola market basket analysis pada data transaksi penjualan atau pembelian konsumen .

6. Implementasi Algoritma Apriori

Adapun langkah-langkah dalam tahapan ini adalah :
a. Analisis Pola Frekuensi Tinggi
b. Pembentukan Aturan Asosiasi

7. Pengujian Hasil

Pada tahap ini, penulis melakukan pengujian dan hasil perancangan sistem menggunakan software Data Mining open source Tanagra. Sistem diuji dengan prosedur-prosedur untuk melakukan eksplorasi dan permodelan dari data-data yang ada sehingga mendapatkan suatu hubungan tersembunyi dari data tersebut.

\section{Hasil dan Pembahasan}

Dari format data transaksi penjualan, maka akan dilakukan Analisis Asosiasi algoritma apriori dengan membuat nilai support yaitu menunjukkan persentasi jumlah transaksi yang berisi nilai $\mathrm{A}$ dan $\mathrm{B}$ dalam kasus ini menunjukan apabila jika membeli Teh,gula maka akan membeli kopi. Analisis asosiasi didefenisikan sebagai suatu proses untuk menemukan semua aturan asosiasi yang memenuhi syarat minimum untuk support (minimum support) dan syarat minimum untuk confidence (minimum confidence) yaitu menunjukkan persentasi banyaknya $\mathrm{B}$ pada transaksi yang mengandung $\mathrm{A}$. pada kasus ini yaitu presentase yang terdapat pada transaksi yang mengandung item teh,gula dan kopi. Untuk menghitung support $A$ digunakan rumus (1) sedangkan untuk menghitung nilai support $A, B$ dapat dilihat pada rumus (2). Berikut ini adalah penjelasan lebih terperinci mengenai tiap-tiap langkah dalam pembentukan Asosiasi dengan menggunakan algoritma Apriori.

\subsection{Data Transaksi Penjualan}

Analisis pola frekuensi tinggi dari kombinasi item pada data transaksi penjualan, adapun data dari transaksi belanja pada Minimarket Ayu dapat dilihat pada Tabel 1.

Tabel 1. Data Transaksi

\begin{tabular}{|c|c|c|c|c|c|}
\hline $\begin{array}{l}\text { Tran- } \\
\text { saksi }\end{array}$ & \multicolumn{5}{|c|}{ Item yang dijual } \\
\hline 1 & Tehh & Gula & Kopi & & \\
\hline 2 & Beras & Susu & Kopi & & \\
\hline 3 & Kopi & Roti & Minyak & Susu & \\
\hline 4 & Gula & Kopi & Roti & Minyak & \\
\hline 5 & Minyak & Beras & Tehh & & \\
\hline 6 & Susu & Beras & Minyak & Roti & \\
\hline 7 & Roti & Kopi & & & \\
\hline 8 & Tehh & Roti & Gula & & \\
\hline 9 & Susu & Beras & Minyak & & \\
\hline 10 & Minyak & Kopi & & & \\
\hline 11 & Gula & Tehh & Minyak & Susu & \\
\hline 12 & Beras & Minyak & Susu & & \\
\hline 13 & Susu & Kopi & Beras & Minyak & \\
\hline 14 & Kopi & Gula & Roti & Minyak & Teh \\
\hline
\end{tabular}

\subsection{Representasi Data Transaksi}

Data transaksi pada Tabel 1 direpresentasikan kedalam bentuk Tabel 2 .

Tabel 2 .Representasi Data Transaksi

\begin{tabular}{cc}
\hline $\begin{array}{c}\text { Kode } \\
\text { Transaksi }\end{array}$ & Item \\
\hline 1 & Beras \\
2 & Minyak \\
3 & Teh \\
4 & Kopi \\
5 & Gula \\
6 & Susu \\
7 & Roti \\
\hline
\end{tabular}

\subsection{Tabulasi Data Transaksi}

Data transaksi pada Tabel 1 di bentuk tabel tabular yang akan mempermudah dalam mengetahui berapa banyak item yang ada dibeli dalam setiap transaksi seperti pada Tabel 3. 
Tabel 3. Format Tabular Data Transaksi

\begin{tabular}{cccccccc}
\hline $\begin{array}{c}\text { Tran- } \\
\text { saksi }\end{array}$ & Beras & Minyak & Teh Kopi & \multicolumn{2}{c}{ Gula } & \multicolumn{2}{c}{ Susu Roti } \\
\hline 1 & 0 & 0 & 1 & 1 & 1 & 0 & 0 \\
2 & 1 & 0 & 0 & 1 & 0 & 1 & 0 \\
3 & 0 & 1 & 0 & 1 & 0 & 1 & 1 \\
4 & 0 & 1 & 0 & 1 & 1 & 0 & 1 \\
5 & 1 & 1 & 1 & 0 & 0 & 0 & 0 \\
6 & 1 & 1 & 0 & 0 & 0 & 1 & 1 \\
7 & 0 & 0 & 0 & 1 & 0 & 0 & 1 \\
8 & 0 & 0 & 1 & 0 & 1 & 0 & 1 \\
9 & 1 & 1 & 0 & 0 & 0 & 1 & 0 \\
10 & 0 & 1 & 0 & 1 & 0 & 0 & 0 \\
11 & 0 & 1 & 1 & 0 & 1 & 1 & 0 \\
12 & 1 & 1 & 0 & 0 & 0 & 1 & 0 \\
13 & 1 & 1 & 0 & 1 & 0 & 1 & 0 \\
14 & 0 & 1 & 1 & 1 & 1 & 0 & 1 \\
Jumlah & 6 & 10 & 5 & 8 & 5 & 7 & 6 \\
\hline
\end{tabular}

\subsection{Pembentukan Itemset}

1 Itemset

Berikut ini adalah penyelesaian berdasarkan data yang sudah disediakan pada Tabel 3 format tabular data transaksi Proses pembentukan $\mathrm{C} 1$ atau disebut dengan 1 itemset didapat berdasarkan rumus (1) analisa pola frekuensi tinggi.

$$
\begin{aligned}
& \text { 1. Support (Beras) }=\frac{6}{14}=0.43 \\
& \text { 2. Support }(\text { Minyak })=\frac{10}{14}=0.71 \\
& \text { 3. Support }(\text { Teh })=\frac{5}{14}=0.36 \\
& \text { 4. Support }(\text { Kopi })=\frac{8}{14}=0.57 \\
& \text { 5. Support }(\text { Gula })=\frac{5}{14}=0.36 \\
& \text { 6. Support }(\text { Susu })=\frac{7}{14}=0.50 \\
& \text { 8. Support } \text { (Roti) }=\frac{6}{14}=0.43
\end{aligned}
$$

Hasil dari perhitungan diatas diubah kedalam bentuk persentase untuk mengetahui confidence dari masing-masing item penjualan, hasil tersebut dapat dilihat pada Tabel 4.
Tabel 4. Support Setiap Item

\begin{tabular}{cccc}
\hline $\begin{array}{c}\text { Kode } \\
\text { Transaksi }\end{array}$ & Item & Jumlah & Confidence \\
\hline 1 & Beras & 6 & $43 \%$ \\
2 & Minyak & 10 & $71 \%$ \\
3 & Tehh & 5 & $36 \%$ \\
4 & Kopi & 8 & $57 \%$ \\
5 & Gula & 5 & $36 \%$ \\
6 & Susu & 7 & $50 \%$ \\
7 & Roti & 6 & $43 \%$ \\
\hline
\end{tabular}

Dari proses pembentukan itemset pada Tabel 4 support setiap item, hasil pembentukan 1 itemset akan dilakukan kombinasi 2 itemset.

Kombinasi 2 Itemset

Proses pembentukan $\mathrm{C} 2$ atau disebut dengan 2 itemset dicari dengan rumus (2) analisa pola frekuensi tinggi, dari Tabel 3 format data tabulasi dapat dilihat pada Tabel 5.

Tabel 5. 2 Item Set

\begin{tabular}{ccc}
\hline \multicolumn{2}{c}{ Nama Item Set } & Jumlah \\
\hline Beras & Minyak & 5 \\
Beras & Tehh & 1 \\
Beras & Kopi & 2 \\
Beras & Gula & 0 \\
Beras & Susu & 5 \\
Beras & Roti & 1 \\
Minyak & Tehh & 3 \\
Minyak & Kopi & 5 \\
Minyak & Gula & 3 \\
Minyak & Susu & 6 \\
Minyak & Roti & 4 \\
Tehh & Kopi & 2 \\
Tehh & Gula & 4 \\
Tehh & Susu & 1 \\
Tehh & Roti & 2 \\
Kopi & Gula & 3 \\
Kopi & Susu & 3 \\
Kopi & Roti & 4 \\
Gula & Susu & 1 \\
Gula & Roti & 3 \\
Susu & Roti & 2 \\
\hline
\end{tabular}


Dari Tabel 5, ditetapkan nilai $\emptyset=4$ sehingga didapat $\mathrm{C} 2=$ $\{($ Beras,Minyak), (Minyak,Kopi), (Beras,Susu), (Minyak,Susu), (Minyak,Roti), (Teh, Gula), (Kopi,Roti)\}.

Kombinasi 3 Itemset

Kombinasi dari itemset pada $\mathrm{C} 2$ bisa digabungkan menjadi 3 itemset. Proses pembentukan $\mathrm{C} 3$ atau disebut dengan 3 itemset dapat dilihat dari Tabel 6.

Tabel 6. Kombinasi 3 itemset

\begin{tabular}{cccc}
\hline \multicolumn{3}{c}{ Nama Itemset } & Jumlah \\
\hline Beras & Minyak & Susu & 4 \\
Beras & Minyak & Kopi & 1 \\
Beras & Minyak & Roti & 1 \\
Minyak & Kopi & Susu & 2 \\
Minyak & Kopi & Roti & 33. \\
Minyak & Kopi & Gula & 2 \\
Minyak & Kopi & Tehh & 1 \\
Tehh & Gula & Kopi & 2 \\
Tehh & Gula & Roti & 2 \\
\hline
\end{tabular}

Dengan demikian,

$\mathrm{C} 3=$ \{(Beras,Minyak,Susu $\} \quad$ karena hanya kombinasi itulah yang memiliki frekuensi kemunculan $>=\emptyset$.

\subsection{Pembetukan Aturan Assosiasi}

Setelah semua pola frekuensi tinggi ditemukan, kemudian dicari aturan asosiasi yang memenuhi syarat Dari C3 yang telah ditemukan, bisa dilihat besarnya nilai support dan Confidence dari aturan asosiasi seperti tabel 7.

Tabel 7. Aturan Asosiasi dari C3

\begin{tabular}{lcc}
\hline \multicolumn{1}{c}{ Rule } & \multicolumn{2}{c}{ Confidence } \\
\hline Jika Beli Beras ,Minyak maka & $4 /$ & 80.00 \\
akan beli Susu & 5 & $\%$ \\
Jika Beli Beras,Susu maka & $4 /$ & 80.00 \\
akan beli Minyak & 5 & $\%$ \\
Jika Beli Minyak,Susu Maka & $4 /$ & 66.67 \\
akan beli Beras & 6 & $\%$ \\
\hline
\end{tabular}

Berdasarkan tabel 7 nilai confidence minimal adalah $80 \%$ sehingga aturan yang bisa terbentuk adalah aturan dengan antecedent berikut :

- Jika Beli Beras,Minyak maka akan beli Susu

- Jika Beli Beras,Susu maka akan beli Minyak

minimum untuk confidence dengan menghitung confidence aturan asosiatif $A \rightarrow B$, nilai confidence dari aturan $A \rightarrow B$ dapat dirumuskan dengan rumus (3) pembentukan aturan asosiasi.

1. Confidence $\mathrm{P}($ Beras $\mid$ Minyak $)=\frac{4}{5}=0.80$

2. Confidence $\mathrm{P}($ Beras $\mid$ Susu $)=\frac{4}{5}=0.80$

nfidence $\mathrm{P}$ (Minyak $\mid$ Susu $)=\frac{4}{6}=0,67$

Untuk membuktikan data-data yang telah dihasilkan berupa pola hubungan kombinasi antar items dan rules-rules asosiasi sesuai dengan Algoritma Apriori maka perlu dilakukan pengujian dengan menggunakan suatu aplikasi. Aplikasi yang digunakan adalah Tanagra versi 1.4 , dengan hasil rule dapat kita lihat pada gam dibawah ini.

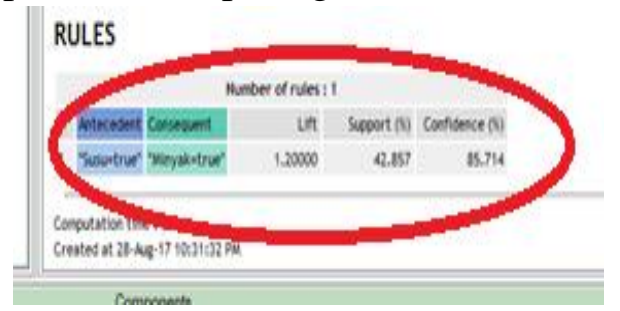

Gambar 2. Pengujian dengan Rules dari pola kombinasi Itemsets

Pada pengujian diatas dengan aplikasi tanagra pengujian untuk menghasilkan rules dari pola kombinasi items. Rules diatas terdiri atas Antecedent, consequent, lift, support(\%), Confidence (\%). Antecedent adalah bentuk kondisi dari pada rules, consequent adalah bentuk pernyataan dari pada rules, lift adalah menunjukkan adanya tingkat kekuatan rules kejadian acak dari antecedent dan consequent berdasarkan pada support masing-masing, 
support adalah persentasi kombinasi items tersebut, sedangkan confidence adalah kuatnya hubungan antar items dalam aturan asosiasi.

Pada kasus Minimarket Ayu rule tertinggi yang muncul pada item barang Minyak dan Susu dengan nilai support $42,85 \%$ dan confidence $85,71 \%$, hal ini sama dengan perhitungan manual algoritma apriori.

\subsection{Kesimpulan}

Berdasarkan pembahasan yang telah dilakukan dengan algoritma Apriori dan dilakukannya pengujian dengan aplikasi Tanagra maka peneliti menarik beberapa kesimpulan yang penting. Adapun kesimpulan-kesimpulan tersebut adalah sebagai berikut:

1. Proses penentuan analisis pola pembelian konsumen dapat dilakukan dengan menerapkan data mining dengan metode algoritma apriori. dengan metode tersebut penentuan pola pembelian dapat dilakukan dengan melihat hasil dari kecenderungan konsumen membeli barang berdasarkan kombinasi 2 itemset. Pengetahuan baru yang dapat diperoleh berdasarkan hasil perhitungan algoritma apriori dan sistem yang dibangun dapat dilakukan pengaturan tata letak barang secara berdekatan untuk memudahkan keberadaan barang tersebut.

2. Penerapan Algoritma Apriori pada teknik Data Mining sangat efisien dan dapat mempercepat proses pembentukan kecenderungan pola kombinasi itemset hasil penjualan barang pokok rumah tangga di Minimarket Ayu TembesiBatam yaitu dengan support dan confidence tertinggi adalah Minyak dan Susu dengan nilai support $42,85 \%$ dan confidence $85,71 \%$.

\subsection{Saran}

Untuk kepentingan lebih lanjut maka peneliti memberikan beberapa saran :
1. Data mining dengan Algoritma Apriori memiliki kelemahan karena harus melakukan scan database setiap kali iterasi, sehingga untuk database yang sangat besar membutuhkan waktu yang lama.

2. Penerapan algoritma Apriori sangat praktis namun perlu dilakukan perbandingan dengan algoritma lain, untuk menguji sejauh mana Algoritma Apriori masih dapat diandalkan untuk memproses dan menemukan pola hubungan (asosiasi) antar item pada database berskala besar

\section{Daftar Rujukan}

Buulolo, E. (2017). Implementasil Algoritma Apriori Pada Sistem Persediaan Obat ( Studi Kasus: Apotik Rumah Sakit Estomihi ).

Fauzy, M., \& Asror, I. (2016). Penerapan Metode Association Rule Menggunakan Algoritma Apriori Pada Simulasi Prediksi Hujan Wilayah Kota Bandung, II(2).

Gamarra, C., Guerrero, J. M., \& Montero, E. (2016). A knowledge discovery in databases approach for industrial microgrid planning. Renewable and Sustainable Energy Reviews, 60, 615630.

Gunadi, G., \& Sensuse, D. I. (2012). Penerapan Metode Data Mining Market Basket Analysis Terhadap Data Penjualan Produk Buku Dengan Menggunakan Algoritma Apriori Dan Frequent Pattern Growth ( FPGROWTH ), 4(1).

Jiawei Han And Micheline Kamber. (2006) . “Data Mining : Concepts and Techi ques ”. San Fransisco : Morgan Kauf mann Publishers

Putro, A. N. S., Ernawati, \& Wisnubhadra, I. (2016). Market Basket Analysis Pada Magister Teknik Informatika , Universitas Atma Jaya Yogyakarta, 978- 
979

Santony, J. (2012). IMPLEMENTASI DATA MINING DENGAN METODE MARKET BASKET ANALYSIS Julius Santony 1, 5(2), 56-63

Santoso, H., Hariyadi, I. P., \& Prayitno. (2016). Data Mining Analisa Pola Pembelian Produk. Teknik Informatika, Subarsono, D. (2014). Perbedaan Pelayanan Pada Ritel Tradisional Dengan Ritel Modern Di Kota Cirebon ., 2(2).

Wulandari, H. N. (2014). Pemanfaatan
(1), 19-24.

Solnet, D., Boztug, Y., \& Dolnicar, S. (2016). An untapped gold mine? Exploring the potential of market basket analysis to grow hotel revenue. International Journal of Hospitality Management, 56, 119-125

Algoritma Apriori untuk Perancangan Ulang Tata Letak Barang di Toko Busana. 